\title{
Charles Dickens's David Copperfield: New Critical Reconsiderations
}

\author{
Ali Albashir Mohammed Alhaj ${ }^{1}$ \\ ${ }^{1}$ Jazan University, Jazan, Kingdom of Saudi Arabia \\ Correspondence: Ali Albashir Mohammed Alhaj, Department of English and Literature, Faculty of Arts \& \\ Humanities, Jazan University, P. O. Box 114, Jazan, Kingdom of Saudi Arabia. E-mail: \\ dr_abomathani@yahoo.com
}

\author{
Received: August 21, 2015 Accepted: October 27, 2015 Online Published: November 29, 2015 \\ doi:10.5539/ells.v5n4p31 URL: http://dx.doi.org/10.5539/ells.v5n4p31
}

\begin{abstract}
The current study aims at reconsidering critically Charles Dickens's David Copperfield. Charles Dickens is perhaps the greatest - if not the most perfect — of Victorian story-teller whose works have become synonymous with Victorian England. Many of his novels came out in monthly installments and were awaited by his readers eagerly. His popularity lay in his ability to write gripping, sentimental stories filled with memorable characters. On a more serious level, his novels are a detailed account of both the good and bad sides of Victorian life. In the semi-autobiographical David Copperfield, the author paints a graphic picture of the living condition of the urban poor. He also denounces the exploitation of children by adults and the cruel competitive nature of Victorian society.

To conclude, characters such as Micawber (a portrait based on Dickens's own father) has passed into folk lore and become household names, used by people who have never read a Dickens novel in their lives. Also, the writer uses too much black paint. However, he wanted to raise kindness and goodness in men's hearts, and he used tears and laughter to reach his aims. He probably brought a little improvement in some condition, but very often, he failed to do so.
\end{abstract}

Keywords: Charles Dickens, David Copperfield, reconsidering critically popularity, Victorian life

\section{Introduction}

The middle third of the nineteenth century saw the peak of the English novel's popularity, and the major figure in this popularity was Charles Dickens (1812-1870). As Chaudhuri (1992) opines:

Dickens has a unique position in English literature for his special form of self-expression in prose, fiction. Dickens's artistic method, his choice of material and his manner of rendering that material, is Dickens's style. The other parts of Dickens's art, his situations, actions and characters and the meaning that they carry, rest upon style and take their essence from it. (p. 32)

Dickens was the first novelists who possessed extreme sensibility with which he felt the sufferings of the poor, an intense imagination with which he depicted their lives, and aroused the conscience of the people. In scope and vitality, and in the creation of enduring characters, Dickens has no rival among English novelists. Dickens has only lately been studied as a literary craftsman. His work was largely conditioned by the fact that he wrote with the press waiting. Like Shakespeare, he was prepared to adapt his material to what his audience required, so that there is no element whatever, in his novels or his journalism, of art for art's sake. Dickens was a shrewd man who in his later years exploited his gifts as a reader of his own stories. He worked himself so hard that he shortened his own life.

Indeed, Dickens is a difficult novelist to write about in a short space of time. Firstly, he is so much the accepted genius of the English novel that he is, like Shakespeare, an institution, and literary institutions can breed a very natural resentment on the part of readers, a resentment that is fuelled by the remaining difficulties. Secondly, in common with a number of other greater novelists, he suffers from the fact that his works, such as A Tale of Two Cities (1859) are often taught in schools. Davies (1990) asserts:

From the proof now available, it is perfectly clear that Dickens studied the art of writing with enthusiasm and zeal...... tending to cumulative excitement, using action in contrast, and introducing symbolic overtones, he is one of the most painstaking of English novelists. 
Dickens dominates the first half of Victoria's reign, and his works help one to discern the centers of interaction between "literature" and "society" in the period. One main chief concern in his work is the description of the "condition of England". Another is the examination of prevailing economic doctrines concerning poverty, population, and the scope of public responsibility. The third is the attempt to suggest more handsome and humanitarian alternatives to those doctrines, a work in which they had the assistance of all those who were influenced by the aspirations of the earlier Romantics, especially of Coleridge, and by the revival of religious feeling and speculation about a more religious order of society (Chaudhuri, 1992).

The basis of Dickens's art, as an observer, as a vivid novelist of nineteenth-century urban life, was his eye for the extreme, the grotesque, and the abnormal. The modern embarrassment that averts its eyes from physical or mental peculiarities, that tries unconsciously to iron the differences between men, could not be further from the distinctive Dickens vision. He seized unerringly on the essential spirit of people, places, atmospheres; he heightened them and he forced the reader to acknowledge the infinite variety and richness of what he saw. Many of his novels are animated by a sense of social injustice. He was the first novelist to fully depict the gloom of urban decay and the consequences of some negative aspects of Victorian times. Dickens was not, however, a radical thinker and his characters never consider rebellion. He stirs the conscience of his contemporaries by showing them scenes of poverty and despair.

Dickens was never an intellectual (a critic has described the theme of all his novels as being that "people should be nicer to each other"), but he was always in close touch with his readers, who came from all sectors of society. $\mathrm{He}$ was an actor of some genius, with an interest in drama and amateur theatrics that at times was obsessive. The frantic energy he showed throughout his life took its toll, as did a near-fatal train crash in which he was involved. He began to give extremely successful public readings from his work, perhaps because he fed off the closeness and immediacy of a live audience and could always write for his readers as much as for himself, but these were also a great strain, and almost certainly contributed to his relatively early death. He was recognized as a genius in his lifetime. Later ages may have changed the vision of what is most valuable in his work; but none has been able to deny that he was a genius.

To conclude, it is, significantly, mainly in the novels that spring from a view of childhood that the of energy is maintained, David Copperfield - a heavily fictionalized but emotionally truthful account of his own childhood - contains some of his engaging caricatures, most notably the gloriously feckless Mr. Micawber (based on Dickens's father) and the repellent Uriah Heep, with his snake-like writhing and his transparently bogus humility. The current study aims at reconsidering critically his undoubted masterpiece (David Copperfield) and some related matters.

\section{Charles Dickens's Contribution, Reputation and Literary Career}

\subsection{Dickens's Life: Family and Social Background}

Charles Dickens, the most popular Victorian novelist, was born in Portsmouth on February 7, 1812. His father, a clerk in the Navy Office, was extravagant and irresponsible with money and consequently life was difficult for the large Dickens family. In 1822 they moved to a poor suburb of London, where Charles's father hoped to find better opportunities when Charles was just twelve years old, his father was imprisoned for debt. Charles was sent to work in appalling conditions in a factory. Memories of this traumatic period inspired much of his later writing, in particular his most autobiographical work David Copperfield (1849-1850). During this unsettled period. Charles's education was almost entirely neglected. However, he became a voracious reader, familiarizing himself with the works of, among others Henry Fielding and Cervantes.

\subsection{Dickens's Contribution, Reputation and Literary Career}

After his father's release from prison, Charles returned briefly to school and then found a job as an office boy. He quickly rose through the ranks, studied short-hand and became a reporter of debates in the Houses of Parliament for a London journal. In 1833 he began writing essays on London life and manners under the pen-name "Boz". These essays were published in several different journals and the readers' favorable response persuaded two publishers named Chapman and Hall to ask him to write accompanying a series for their humorous sporting sketches by a popular comic artist named Seymour. Thus came Mr. Pickwick in a flash. The sudden flash of inspiration in which Dickens thought of Mr. Pickwick was really the foundation of all his amazing triumphs. At first the Pickwick Papers (1836-1837) was not particularly popular; the tide turned in an astonishing way when, with another flash of genius, Dickens thought of Sam Weller. From the moment Mr. Pickwick's cheerful cockney servant made his appearance Dickens's name and fame were assured. 
Dickens is one of the masters of prose in his own way, though his style cannot be admired for flow of pure idiom or command of subtle melodies. His style is often too much mannered. At its best Dickens's style is neither polished nor scholarly, but it is clear, rapid and workmanlike, the style in the early books is spoiled by funs, cockneyisms, and tiresome circumlocutions. The style of David Copperfield is simple, direct and forcible

Dickens dedicated his considerable energies and talent to writing, and the quantity and often the quality of his output was phenomenal. Between 1837 and 1843 he wrote Oliver Twist, Nicholas Nickleby, The Old Curiosity Shop and A Charismas Carol, all initially published in serial the two Charismas books in between, he started writing David Copperfield in 1849. There were more to come; Bleak House (1852-1853), Hard Times (1854), Little Dorrit (1855-1856). After the separation with his wife came A Tale of Two Cities. In 1864, he brought out Great Expectations (1860-1861) to be followed by Our Mutual Friend (1864-1865). He carried on his frantic professional life until he had a mild stroke. He cancelled some of his readings but began one more novel which was never completed.

Despite the weighty themes, all of Dickens's novels show touches of the comic genius which launched his literary career. His first novel the Pickwick Papers (1836-1837), is still considered to be one of the supreme comic novels in the English language. Characters such as Mr. Bumble in Oliver Twist, Mr. Bounderby in Hard Times and Mr. Micawber in David Copperfield add humor to otherwise gloomy worlds. Often farcical and caricatural, Dickens created innumerable and memorable characters in his novels, and is often compared to Shakespeare in his ability to capture the essence of a personality in just a couple of lines.

It is a fascinating and almost lifelong exercise to trace the way that Dickens's society permeates his novels. Perhaps one of the most surprising points to make about his novels is that very often they ignore the later part of nineteenth century, and look back to the pre-1850s when the full effects of the Industrial Revolution were yet to be felt. There is a strong element of nostalgia for the old world of the stagecoaches in Dickens's novels. Equally, some of his novels deliberately stage confrontation between the old and the new, as when Sir Leicester Dedlock is brought face to face with the "ironmaster" or industrialist in Bleak House. Dickens's attitudes can be cloudy. He spots that the ironmaster is here to stay, feels he should like him, but actually shows more genuine affection (mingled with applied exasperation) for the old nobility. At other times Dickens charge head-on into the new world, though a novel such as Hard Times (1854), based on the new industrial life, suggests he was happier with the London he loved and knew.

Dickens's novels may seem overly sentimental and pedantic to today's reader. This is due to the fact that he wrote to please his public - a public which demanded that he respected the prevailing morality and conventions of the time. Despite these considerable restraints, Dickens's unquestionable literary genius emerges in his work. $\mathrm{He}$ is still considered by many to be the greatest of all novelists in the English language.

Dickens's stories and sketches, especially the later one, abound in fine dramatic situations of incalculable help to him as a painter of London life. The drama sometimes degenerates into melodrama, which in itself was again a conventional device which readers of today cannot appreciate. But melodramatic element is chiefly noticeable in his early works like, Oliver Twist and Nicholas Nickleby, while the simple poignancy, the restraint and dignity of his scenes from David Copperfield onwards are admirable. As Compton-Rickett (1990, p. 69) rightly observed:

None but a genuine dramatic artist could modulate his style as Dickens can so as to take on the mood of the moment.

To conclude, Dickens's novels are all animated by a sense of injustice and personal wrong; he is concerned with the problems of crime and poverty, but he does not seem to believe that matters can be improved by legislation or reform movements - everything depends on the individual, particularly the wealthy philanthropist (Pickwick or the Cheeryble brothers), if he has a doctrine, it is one of love.

\section{Charles Dickens's David Copperfield: Sound Critical Reconsiderations}

\subsection{Charles Dickens and Idea of David Copperfield}

Charles Dickens's David Copperfield is famous for its opening, which is more or less autobiographical, and contains a portrait of Dickens's father in Mr. Micawber. As Compton-Rickett (1990, p. 67) opines:

Mr. Micawber is another type of the attractive mercurial temperament, ready to look on the bright side of things at the smallest provocations. Apart from this, the needy, improvident man would have served the stern moralist's purpose almost as well as Swiveller. But really we are scarcely conscious of his faults, so delighted are we by his company. 
Mr. Micawber is a very famous character, and a common subject in examinations. Another standard question concerns the narrative technique of the novel and in particular, its masterly use of the point of view technique. Uriah Heep and Steerforth are often the focus of questions, the former as a powerful caricature, and the latter as a relative failure in the creation of an ideal vision of general society. Characterization of women and whether Dickens makes David marry the wrong person all along, can also come in for attention. Equally, the Peggoty family is a masterpiece, and shows Dickens's imagination working at its most vivid, powerful and endearing.

\subsection{David Copperfield as Charles Dickens's Undoubted Masterpiece}

In 1849-1850 appeared David Copperfield which for most readers is Charles Dickens's Undoubted Masterpiece. The novel is partly based on the early career of the writer himself; though there were not many people who were in the framing of the secret, that little David was in so many ways close to Charles Dickens at a comparative age. The novel proved immensely popular; it is one of the greatest novels in English and is one of those works of Dickens whose popularity has never waned.

\subsection{The Story of the Novel: At a Glance}

Following the death of his father, David's mother, Clara, remarries. She dies soon after, so David is left in the care of his cruel and tyrannical stepfather, Mr. Murdstone, and his just as unpleasant sister, Miss. Murdstone. David runs away and starts to build a life for himself. He continues his studies in Canterbury and finds a job as a clerk in London. He does not like his job but he has a wide range of contacts and fiends, among whom the most memorable are the impecunious but lovable Mr. Micawber, and the conniving, greedy Uriah Heep. He marries Dora, a pretty but silly girl, and launches out on a new career as a writer. When Dora dies; he marries his lifelong friend, Agnes, and becomes a successful writer.

\subsection{Dickens's Sentimentality in the Novel}

The most extreme attack on Dickens's sentimentality is argued in a book by Kingsmill Lunn (1990) entitled "The Sentimental Journey". The case is that Dickens deteriorated as he grew older, his sentiment became more maudlin, and his character decayed so much that he finally left his wife for Ellen Ternan. In replying to this charge Earle Davies (1990) convincingly shows us in his study of the artistry of Dickens, that:

artistically it is completely wrong. Dickens was still sentimental when he died, but from David Copperfield on, his novels show more restraint and control of the means by which he appealed to tears. His characters weep less and less. Furthermore, it would be very difficult to criticize him for mawkish sentimentality in the latter half of his career on the basis of his death scenes.

In David Copperfield, for example, Dora dies and her death affects David as any reader will admit that it should. But Dora had never been described as a majestic angel, like Little Nell. She was in some measure human, with weaknesses which contribute to her normality. David, as he waits for Agnes to come back from the death chamber, wonders: Would it, indeed, have been better if we had loved each other as a boy and a girl, and forgotten it? (David Copperfield, p. 67). Since in real life he had never married the prototype of Dora, this question is illuminating. And yet, when Dora dies, Jep (the dog) dies too. There is sentiment present, of course, but it cannot be accurately described as weak or mawkish.

\subsection{The Portrayal of the Personal Life and Marriage in the Novel}

David Copperfield is a novel about the personal life: through it Dickens announces the value of the individual experience, the right of human beings to privacy, personal freedom, the happy satisfaction of private interests and the possibility of mature relationships with others. These are not won without difficulty, and, as the examples of Emily and Martha 'Endell, there is a special difficulty for women whose "freedom" seems entirely dependent upon men.

David Copperfield describes David's achievement of maturity, but it is also concerned with the theme of marriage. David has some of the characteristics of Tom Jones: his period of apprenticeship is devoted to preparing him for a life of domestic happiness. Henry Fielding does not discuss the question of how this happiness is to be achieved: Sophia's beauty and virtue are sufficient guarantees of successful, marriage. Dickens is aware of human complexities, which go beyond this simple view. David's first marriage to Dora Spenlow is unhappy because it is not a marriage of minds and purposes.

David Copperfield is studded with unhappy personal relationships, with bad marriages and inadequate fathers. His mother's second marriage to Mr. Murdstone was disastrous; his aunt Betsey Trotwood married a man who spent her fortune, broke her heart and became a bigamist, an adventurer, a gambler and a cheat. Dr. Strong, the 
unworldly master of David's second school, finds that his marriage to a much younger woman has been manipulated by her relatives to their own mercenary ends; the marriage of Mr. and Mrs. Micawber is a tragicomic match between slovenliness and improvidence; even Traddles, whose wife is devoted to him, has to cope with the demands of her extensive family.

Also, David's pain and unhappiness in his marriage to Dora are expressed but, not fully explored: conventionally falling into a decline, she dies and leaves the way clear for Agnes Wickfields, who has always been David's true love.

\subsection{The Depiction of Mr. Micawber as a Comic Character}

The gallery of Dickens's comic characters is so huge that one does not know where to begin. It is here, that we find the value of a static character (in Forster's word "flat" character). As Robert Liddell (1999) points out, "almost every successful comic character is flat", for we do not expect a comic character to put on three dimensionalities. When he does this and thereby abandons his stock phrase and says something quite different, we are disappointed. According to Chaudhuri (1992, p. 177):

A comic character like Mr. Micawber which must necessarily be flat or static is likely to be more complicated and enigmatic than a hero or heroine, full of surprises and turn-abouts. Mr. Micawber, for example can find the most unexpected ways of being himself. It is a kind of resourcefulness. The strength of this type of characters lies in their immunity to the knocks and upheavals which they face- these cannot change their selves - they reassert their own natures.

\section{Conclusion}

Dickens's great comic creations like Mr. Micawber present forms of absurdity not to be found in human nature, and therefore, hardly amenable to moral categories. It is this positive quality that makes the humor of Dickens so difficult to analyze, and so easy to enjoy. Dickens is a master of grotesque and his characters are really humors - exaggerations of a human quality to the point of caricature. Mr. Micawber is personified optimism, Uriah Heep mere creeping hypocrisy, Mr. Squeers a monster of ignorance and tyranny - they are grotesque, not human beings at all.

In his novels, Dickens describes and attacks many kinds of unpleasant people and places in general but in David Copperfield in particular, there is the sense that society is pervaded by ruthless egotism and needs a radical moral reformation. The novel despite the Murdstoness, Creakle, Steerforth, Uriah Heep and his mother, lacks this sense. Except in the early episode of David's conflict with the Murdstones, the emphasis is on the need for personal disciplines not on the need for caritas.

This shift in orientation is reflected in the marriages which make up the plot. In earlier novels a bad marriage was a mercenary one, characteristically forced on young people by their calculating elders: in David Copperfield most of bad marriages are disinterested, innocent, and impulsive while the good marriages-Peggotty's to Barkis, Annie to Dr. Strong, David's to Agnes - are passionless and carefully weighed.

\section{References}

Chaudhuri, B. P. (1992). Charles Dickens: Oliver Twist. New Delhi: Goldy Printer.

Davies, E. R. (1990). The Flint and the Flame: The Artistry of Charles Dickens. London: Macmillan.

Kings, H. L. (1991). The Sentimentality of Charles Dickens. London: Macmillan.

Liddell, R. (1999). Charles Dickens. London: Macmillan.

Milligan, I. (1997). The Novel in English. An Introduction. London: Oxford University Press.

Raban, R. (1988). The Technique of Modern Fiction. London: Edward Arnold.

Rickett, A. (1990). History of English Literature. London: Oxford University Press.

Stevenson, L. (1994). The English Novel. A Panorama. London: Oxford University Press.

Watt, I. (1991). The Rise of the Novel. Cambridge: Cambridge University Press.

Wisonm, A. (1993). The World of Charles Dickens. London: Oxford University Press.

\section{Copyrights}

Copyright for this article is retained by the author(s), with first publication rights granted to the journal.

This is an open-access article distributed under the terms and conditions of the Creative Commons Attribution license (http://creativecommons.org/licenses/by/3.0/). 